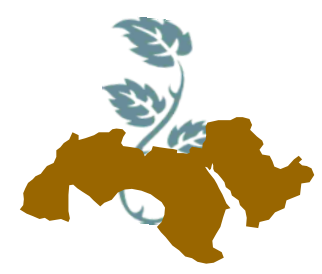

Arab Univ.

J. Agric. Sci., Ain Shams Univ., Cairo, 24(1), 207-218, 2016

\title{
IMPLEMENTATION OF HAZARD ANALYSIS CRITICAL CONTROL POINTS (HACCP) PRINCIPLES IN PRODUCTION OF FILLING CREAM
}

\author{
Abd El-Rady, M.F. ${ }^{1}$, Nagwa, M.H. Rasmy ${ }^{2}$, Nessrien M. Yasin ${ }^{2}$, \\ M.M. Abd El-Razik ${ }^{3}$ and H.A. Fahmy ${ }^{1}$ \\ 1- Quality control Dept., Food Techn. Res. Inst. (FTRI), Agric. Res. Center (ARC), Giza, Egypt \\ 2- Food Sci. Dept., Faculty of Agric., Ain Shams University, Cairo, Egypt \\ 3- Food Science \&Human Nutrition Dept, College of Agric. and Veterinary Medicine, Qassim \\ University, Kingdom of Saudi Arabia \\ *Corresponding author, email: fawzicacid@yahoo.ca
}

Keywords: Control measures, Filling cream, HACCP, milk powder, pathogens, Safety.

\section{ABSTRACT}

For improving the safety of filling cream, the Hazard Analysis Critical Control Points (HACCP) system was applied during different preparation process. Different biological, chemical, and physical hazards that may exist in every preparing step of filling cream were identified and control measures were used for controlling those identified hazards. Dried milk powder was identified as high potential hazard raw materials contaminated with pathogenic bacteria e.g. S. aureus and Salmonella $s p$. Whipping step in preparing filling cream was identified as critical control point. For improving the safety of preparing filling cream system, different control measures including, thermal processing (pasteurization), addition of natural preservatives (lemongrass oil and herbs of cinnamon, clove and anise) and reduction of $\mathrm{pH}$ (fruit pulps of strawberry, apricots and apple) were established. Different applied control measures could be used for improving the safety of prepared filling cream where different investigated microbiological criteria were reduced to acceptable levels especially pathogenic bacteria. In addition, different HACCP principles as the critical control points, critical limits, monitoring, corrective measures, verifications and records were established. Implementing the HACCP system during preparing filling cream can effectively ensure safety of this product and other food products contained filling cram especially bakeries.

\section{INTRODUCTION}

Filling creams are generally fat and sugar based; they are important components in different confectionary foods, in which they provide taste, texture and adhesion of the baked items, (Nicoletta et al 2015). Filling creams are basically sugar and fat mixtures, even if also other ingredients are included in the recipe (Manley, 2001). Sugars are generally the main ingredients; sucrose is the most used one (Birkett, 2009). It acts both as sweetener and as bulking agent and also affects some sensory properties such as sweetness, hardness and dryness of the final product. Fat content in filling creams varies from 30 to $60 \%$, and has an enormous effect on the sensory and rheological properties. Basically the consistency of a filling cream is determined by the solids content of the fat (Manley, 2001). Bakery products are one of the most popular products in the Egyptian markets particularly products stuffed with cream. May touch on the mind from the first glance that there is no microbiological seriousness of these products because they are exposed to high temperatures during backing process. But must keep in mind that some of these products contain materials that sensitive such as cream and chocolate, which no conduct the heat treatment. These materials are added to the product after backing - and there are many factors that helped to create a risk of bakery products such as presence of sensitive materials in the components of the filling materials such as powdered milk, eggs, sugar (Leitenberger and Röcken. 1998). Actually, $5 \%$ of food poisoning 
cases reported by Todd (1978) occurred as result of consumption of bakery products contaminated by Staphylococcus aureus. According to International Commission on Microbiological Specification for Foods "ICMSF" (1980), baked goods are made of grains that are frequently contaminated by bacterial spores. During proofing of dough, microbial growth occurs. Temperatures attained during baking kill vegetative forms of pathogens and lower water activity of the baked products. Baked goods are sometimes filled, layered or covered with substances e.g., custard, whipped cream and butter cream that may either contain pathogens e.g., Salmonella spp. or support microbial growth. Thereby, many filling materials are excellent microbial growth media. Others are only minimally good substrates or they may even be inhibitory to microbial growth because of one or more limiting factors, such as low water activity, low $\mathrm{pH}$ or limited nutrients. Preservation is accomplished by alteration of formulation, refrigeration or preservatives. Erol et al (1996) examined, 15 samples of butter-cream, 53 samples of chocolate-cream and 32 samples of fruit-cream pastry for microbiological quality, and they found that, mean count of aerobic bacteria were $6.3 \times 10^{7}, 5.3 \times 10^{6}$ and $1.7 \times 10^{7}$ $\mathrm{cfu} / \mathrm{g}$, respectively. Mean count for Enterobacteriaceae, Coliform and Enterococci were $10^{3}, 10^{1}$ to $10^{2}$ and $10^{3}$ to $10^{4} \mathrm{cfu} / \mathrm{g}$, respectively. Most samples contained Pseudomonas, yeast and molds at counts of $10^{3}$ and $10^{4} \mathrm{cfu} / \mathrm{g}$, respectively. Salmonella spp. was not detected in $25 \mathrm{~g}$ of different samples. They concluded that, hygienic quality of pastries is inadequate. Brack (1996) cleared that, certain bakery ingredients especially filling which undergo no minimum heat treatment that may present microbiological risks, as demonstrated by HACCP. Decreasing water activity and $\mathrm{pH}$ of the filling could minimize this risk, and increasing sugar concentration, replacement of sucrose, could do this by glucose and addition of glycerin and acids. HACCP system is a systematic approach to the identification, assessment of risk and control of the biological, chemical and physical hazards associated with each segment of the food system from production to consumption, following the seven basic principles, 1) Identification of hazards that may be present from harvest through ultimate consumption and preventive measures for controlling them, 2) Determination of Critical Control Points (CCPs) required to control the identified hazards, 3) Establishment of critical limits that must be met at each CCP, 4) Establish appropriate monitoring procedures for each identified CCPs, 5) Establish- ment of corrective actions should be taken when CCPs are not under control, 6) Establishment of procedures for verification that HACCP system is working according to the plan and 7) Documentation records concerning all procedures and records appropriate to principles 1 through 6, (National Advisory Committee on Microbiological Criteria for Foods: NACMCF,1998). In general, HACCP aims to eliminate influences that result in food borne diseases in humans from the production, handling, treatment, transportation and storage of foods. (Sivasankar, 2002 \& Gandhi, 2008).

The main goal of this study was to implement a HACCP principles during filling cream preparation. The quality and safety of produced filling cream were evaluated.

\section{MATERIALS AND METHODS}

\section{1- Materials}

The raw materials used in manufacturing of filling cream: sucrose, shortening, milk powder, lemongrass oil and natural herbs (cinnamon, clove, and anise) were purchased from local market, Cairo, Egypt. Natural fruit pulps: strawberry, apricots, and apples were obtained from International Company for Food Industries., 6th October, Egypt.

\subsection{Methods}

\subsubsection{Preparation of filling cream}

This experimental study was conducted through laboratory scale for the preparation of filling cream. The flow chart of preparation steps of filling cream was illustrated in Fig. (1). For controlling the safety of prepared filling cream the following control measures were used: (1) Pasteurization at $80^{\circ} \mathrm{C}$ for 10 minute. (2) Addition of lemongrass oil at concentrations of 1,2 and $3 \mu \mathrm{l} / \mathrm{g}$ of filling cream. (3) Addition of cinnamon, clove and anise as natural herbs. (4) Addition of natural fruit pulps: strawberry, apricots, and apples. The best levels of natural herbs and natural fruit pulps achieved good sensory attributes through several trials were chosen for preparing filling cream in this study. Different prepared filling cream were aseptically packaged in glass bottles and stored at $4^{\circ} \mathrm{C}$ until analysis. 


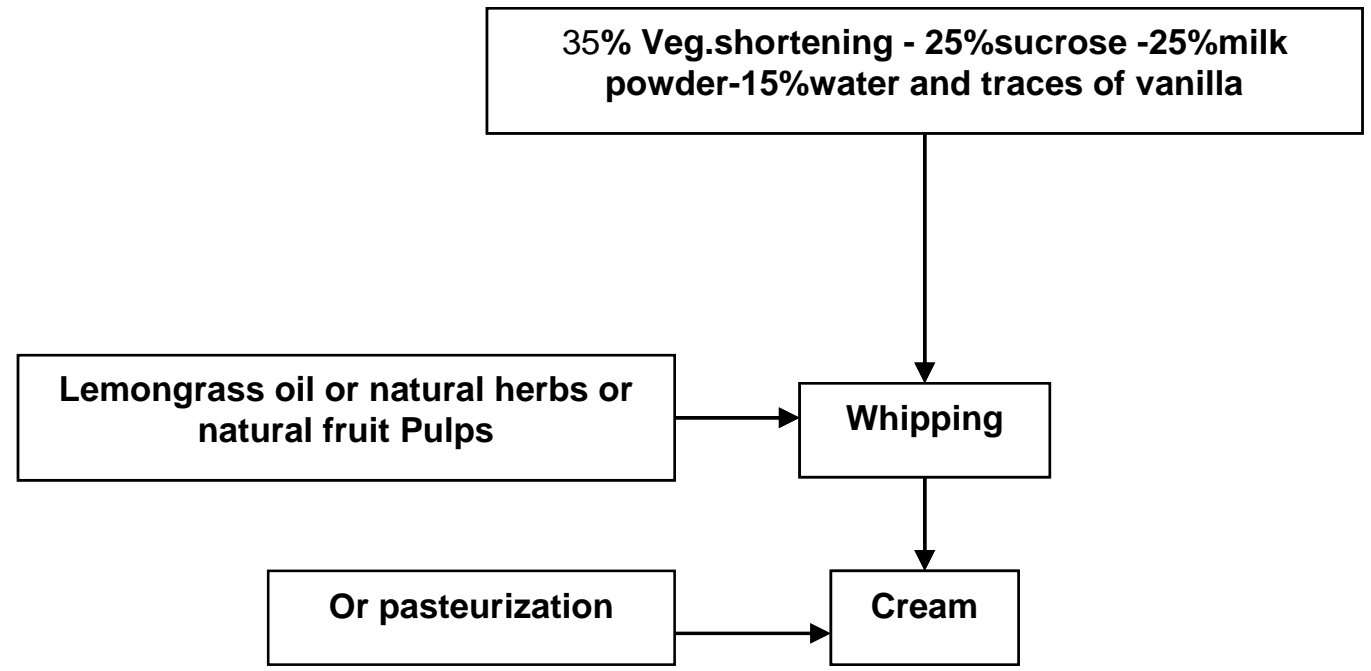

Fig. 1. Flow diagram of filling cream manufacture

\subsubsection{Analytical methods}

Different prepared filling cream, samples were microbiologically analyzed after 24 hours of preparation for total aerobic bacterial count (ISO 4833, 2003) yeast and mold count (ISO 21527-1,2, 2008), Escherichia coli (ISO 4832, 2006), Staphylococcus aureus counts (ISO 6888-1, 2003) and presence of Salmonella sp. (ISO 6579, 2002).

Different prepared filling cream samples were aseptically collected, and $10 \mathrm{~g}$ from each was homogenized in $90 \mathrm{ml}$ of sterile diluent $(0.1 \%$ peptone water) with a Stomacher (Seward, Model 400, England) for $30 \mathrm{Sec}$. Serial dilutions were prepared in peptone water and $1 \mathrm{ml}$ aliquots were plated in each specific medium and incubated at different temperatures as listed in Table (1). Aerobic spore forming bacterial count was determined according to the method of APHA (2001), serial dilutions of different filling cream samples were pasteurized at $80^{\circ} \mathrm{C}$ for $10 \mathrm{~min}$ and $1 \mathrm{ml}$ aliquots were plated in plate count agar medium. Five filling cream samples were examined for the presence of salmonella. $\mathrm{sp}$ and the percentage of positive sample was calculated. Twenty five gram from each filling cream sample was pre-enrichment in $225 \mathrm{ml}$ of peptone water and incubated at $37^{\circ} \mathrm{C}$ for 16 to $24 \mathrm{~h}$. For selective enrichment, $1 \mathrm{ml}$ of peptone broth was transferred to $9 \mathrm{ml}$ each of tetrathionat broth and was incubated at $42^{\circ} \mathrm{C}$ for $24 \mathrm{~h}$. From each selective enrichment broth a 5-mm loopfull was streaked on selective plates of bismuth sulfite agar and incubated at $37^{\circ} \mathrm{C}$ for $24 \mathrm{~h}$.
Table 1. Media and incubation conditions used for microbiological analysis

\begin{tabular}{|c|c|c|c|}
\hline \multirow{2}{*}{$\begin{array}{l}\text { Microbiological } \\
\text { analysis }\end{array}$} & \multicolumn{3}{|c|}{ Incubation } \\
\hline & $\begin{array}{l}\text { Time } \\
\text { (h) }\end{array}$ & $\begin{array}{l}\text { Temp } \\
\left({ }^{\circ} \mathrm{C}\right)\end{array}$ & $\begin{array}{c}\text { Growth } \\
\text { medium }\end{array}$ \\
\hline $\begin{array}{l}\text { Total aerobic bacte- } \\
\text { rial count }\end{array}$ & 48 & 37 & $\begin{array}{c}\text { Plate count } \\
\text { agar }\end{array}$ \\
\hline $\begin{array}{l}\text { Aerobic spore form- } \\
\text { ing bacteria }\end{array}$ & 48 & 37 & $\begin{array}{l}\text { Plate count } \\
\text { agar }\end{array}$ \\
\hline $\begin{array}{l}\text { Yeast and mold } \\
\text { count }\end{array}$ & $\begin{array}{l}72- \\
120\end{array}$ & 25 & $\begin{array}{c}\text { Potato } \\
\text { dextrose agar }\end{array}$ \\
\hline E. coli & 24 & 44.5 & $\begin{array}{l}\text { MacConkey } \\
\text { agar }\end{array}$ \\
\hline $\begin{array}{l}\text { Staphylococcus } \\
\text { aureas }\end{array}$ & 48 & 37 & $\begin{array}{c}\text { Baird parker } \\
\quad \text { agar }\end{array}$ \\
\hline Salmonella spp. & & & \\
\hline Pre-enrichment & $16-24$ & 37 & $\begin{array}{c}\text { Buffer peptone } \\
\text { water }\end{array}$ \\
\hline $\begin{array}{l}\text { Selective enrich- } \\
\text { ment }\end{array}$ & $24-48$ & 41 & $\begin{array}{c}\text { Tetrathionate } \\
\text { broth }\end{array}$ \\
\hline Isolation & $24-48$ & 37 & $\begin{array}{c}\text { Bismuth sulfite } \\
\text { agar }\end{array}$ \\
\hline
\end{tabular}

The $\mathrm{pH}$ of prepared filling cream contained different amounts of natural fruit pulps(i.e. strawberry, apricots, and apples) was determined as follows: A $30 \mathrm{~g}$ of different prepared cream filling was blended with $100 \mathrm{ml}$ distilled water and the $\mathrm{pH}$ of the slurry was then measured using a $\mathrm{pH}$ meter (HANNA-Instrument, USA). 


\subsubsection{Application of HACCP principles}

Based on the United Nation Codex Alimentarius Commission's HACCP and guidelines for its application, (2003) the principles of HACCP were applied during different preparation steps of filling cream. The preparation steps of filling cream were drawn and a hazard analysis was performed with the control measures which could be used in controlling different identified hazards. CCPs were subsequently identified by using decision tree. Critical limits were established, as well as monitoring procedures, corrective actions, records, documentations and verification.

\section{RESULTS AND DISCUSSION}

The first step in planning a HACCP plan for any food product is description of product therefore, different characteristics of prepared fill cream are tabulated in Table (2). The identified characteristics especially related to the food safety, (codex, 2003) were product name, raw materials used in preparing product, important characteristics, intended use \& how the product is to be used, packaging, shelf life, where the product will be sold, labeling instructions and special distribution control. The important characteristics with related the safety of product as controlling measures for microbial growth are $\mathrm{pH},(4.53$ to 6.58$)$ and total soluble solids, (68.71 to $68.84 \%$ ). It could be noticed that $\mathrm{pH}$ levels of filling cream are more suitable for microbial growth especially pathogenic bacteria e. g. Salmonella sp., these notices were agreement with the observation reported by Letienberger and Röcken, (1998). So; controlling of the $\mathrm{pH}$ of filling cream, addition natural preservatives and thermal processing were the most controlling measures which could be used in this study for preventing microbial growth in the final product.

Risk category of prepared filling cream was evaluated according to NACMCF, (1992), and the results are presented in Table (3). Hazard characteristics of filling cream was $(+++++)$ as it contains sensitive ingredients and there is no a controlling processing step could be used in preventing microbial growth, Also filling cream is subjected to recontamination after preparing, there is substantial potential for abusive handling after preparing and there is no terminal heat process after packaging the final product, so filling cream was identified as risk group of IV.
Table 2. Description of prepared filling cream

\begin{tabular}{|c|c|}
\hline Item & Description \\
\hline Product name & Filling cream. \\
\hline $\begin{array}{l}\text { Raw materials of } \\
\text { product }\end{array}$ & $\begin{array}{l}\text { Sucrose, shorting, milk } \\
\text { powder and vanilla. }\end{array}$ \\
\hline $\begin{array}{l}\text { Important character- } \\
\text { istics of product }\end{array}$ & $\begin{array}{l}\text { pH 4.53- 6.58, T.S.S 68.71- } \\
68.84 \%\end{array}$ \\
\hline $\begin{array}{l}\text { How the product is } \\
\text { to be used }\end{array}$ & $\begin{array}{l}\text { Normally used in filling and } \\
\text { coated bakery and confec- } \\
\text { tionery products. }\end{array}$ \\
\hline Packaging & $\begin{array}{l}\text { Sealed polythene bags / } \\
\text { hermetically sealed metal } \\
\text { container. }\end{array}$ \\
\hline Shelf life & $\begin{array}{l}\text { From three to six months at } \\
\text { normal retail shelf tempera- } \\
\text { ture. }\end{array}$ \\
\hline $\begin{array}{l}\text { Where the product } \\
\text { will be sold }\end{array}$ & $\begin{array}{l}\text { Retail, institutions and food } \\
\text { service. }\end{array}$ \\
\hline Labeling instructions & $\begin{array}{l}\text { Required to ensure product } \\
\text { safety. }\end{array}$ \\
\hline $\begin{array}{l}\text { Special distribution } \\
\text { control }\end{array}$ & $\begin{array}{l}\text { No physical damage, excess } \\
\text { humidity or temperature } \\
\text { extremes and microbial } \\
\text { growth. }\end{array}$ \\
\hline
\end{tabular}

Table 3. Risk category of filling cream

\begin{tabular}{|c|c|c|}
\hline Product & Hazard characteristics & Risk category \\
\hline $\begin{array}{l}\text { Filling } \\
\text { cream }\end{array}$ & +++++ & IV \\
\hline
\end{tabular}

NACMCF (1992).

+ : indicate presence of potential hazards

According to Codex, (2003), to conduct a hazard analysis during preparing filling cream it is necessary to prepare a list of raw materials and processing steps in the process of product under investigation (filling cream) where significant hazards occur. A list of all identified hazards associated with each raw material used in preparing filling cream, processing step, and established control measures are shown in Table (4). It could be noticed that, the potentially hazards of raw materials were differentially according to their natural and microbiological flora associated with the materials, 
Table 4. Hazard analysis and control measures of raw materials used in preparing filling cream and its preparing steps

\begin{tabular}{|c|c|c|}
\hline $\begin{array}{l}\text { Preparing step } \\
\text { Receiving raw materials }\end{array}$ & Hazard & Control measures \\
\hline Sucrose & $\begin{array}{l}\text { B: Spore forming bacteria, yeast \&mold. } \\
\text { C: Mold toxin and pesticides residues. } \\
\text { P: Foreign materials. }\end{array}$ & $\begin{array}{l}\text { Certified suppliers, complains } \\
\text { with raw materials specifica- } \\
\text { tions and sieving. }\end{array}$ \\
\hline Milk powder & $\begin{array}{l}\text { B: Salmonella spp., Listeria monocytogenes, } \\
\text { E. coli and Staph. aureus } \\
\text { C: Pesticides residues, antibiotics, hor- } \\
\text { mones, heavy metals, cleaning chemicals } \\
\text { and food additives. } \\
\text { P: Foreign materials. }\end{array}$ & $\begin{array}{l}\text { Certified suppliers, complains } \\
\text { with raw materials specifica- } \\
\text { tions. }\end{array}$ \\
\hline Shorting & $\begin{array}{l}\text { B: Not usually. } \\
\text { C: Substances resulted from rancidity and } \\
\text { unlimited antioxidants. } \\
\text { P: Not usually. }\end{array}$ & $\begin{array}{l}\text { Certified suppliers, complains } \\
\text { with raw materials specifica- } \\
\text { tions. }\end{array}$ \\
\hline Vanilla & $\begin{array}{l}\text { B: Not usually. } \\
\text { C: Environmental chemicals and heavy met- } \\
\text { als. } \\
\text { P: Foreign materials. }\end{array}$ & $\begin{array}{l}\text { Certified suppliers, complains } \\
\text { with raw materials specifica- } \\
\text { tions. }\end{array}$ \\
\hline Whipping & $\begin{array}{l}\text { B: Pathogenic bacteria, spore forming bacte- } \\
\text { ria and yeast \& mold. } \\
\text { C: Not usually. } \\
\text { P: Not usually. }\end{array}$ & $\begin{array}{l}\text { Pasteurization, addition of } \\
\text { natural preservatives and } \\
\text { acidification of prepared } \\
\text { cream. }\end{array}$ \\
\hline
\end{tabular}

B: Biological, C: Chemical and P: Physical hazards.

(NACMCF, 1992, Corlett, 1998, ICMSF, 2005 and FSSAI, 2015). According to the results tabulated in Table (4), it could be reported that, milk powder was the main potentially hazard raw materials used in preparing filling cream especially pathogenic bacteria as reported by ICMSF, (2005), Ledenbach \& Marshall, (2009) and FSSAl, (2015). About control measures of identified hazards it could be suggested that, certified suppliers and complains with raw materials specifications could be used for preventing different hazards (biological, chemical and physical) especially in receiving step of raw materials. In the same time during processing step application of good manufacturing practices (GMP) and controlling the processing step as sieving for controlling physical hazards associated in raw materials where pasteurization, addition of preservatives and controlling $\mathrm{pH}$ of prepared filling cream could be used in controlling biological hazards especially pathogenic bacteria which could contaminate raw materials especially milk powder.
Completing hazard analysis of filling cream, different raw materials used in preparing it were microbiologically analyzed and the results are shown in Table (5). Microbiological load of sucrose were satisfactory, where total bacterial count, spore forming bacterial and yeast \& mold counts were $2.00,2.18$ and $2.3 \mathrm{log} \mathrm{cfu} / \mathrm{g}$, respectively, In the same time, microbiological load of shortening were not exceed of $2.00 \mathrm{log} \mathrm{cfu} / \mathrm{g}$ for, total bacterial counts and counts of spore forming bacteria, while yeast \& mold counts were not detected at detection limit $<10^{1} \mathrm{cfu} / \mathrm{g}$. Furthermore, counts of $E$. coli. and $S$. aureus. were not detected at detection limit $<10^{1} \mathrm{cfu} / \mathrm{g}$ and Salmonella sp. was not detected in any tested samples of sucrose and shortening. On the other hand, microbiological load of the tested milk powder was unsatisfactory where values of total bacterial count, spore forming bacterial, yeast \& mold counts, E. coli. and S. aureus. counts were 2.78, 2.60, 2.30, 2.54 and $1.60 \log$ $\mathrm{cfu} / \mathrm{g}$, respectively, in the same time, Salmonella sp. was detected in one sample of five tested 
Table 5. Microbiological analysis of raw materials used in preparing filling cream

\begin{tabular}{|cccccccc|}
\hline Raw materials & $\begin{array}{c}\text { Total bacterial } \\
\text { count }^{*}\end{array}$ & $\begin{array}{c}\text { Spore forming } \\
\text { bacterial } \\
\text { count }^{*}\end{array}$ & $\begin{array}{c}\text { Yeast and } \\
\text { mold count }^{\star}\end{array}$ & E. coli ${ }^{\star}$. S. aureus.* & $\begin{array}{c}\text { Salmonella } \\
\text { sp. }^{* *}\end{array}$ \\
\hline Sucrose & 2.00 & 2.18 & 2.30 & $<1$ & $<1$ & ND \\
Milk powder & 2.78 & 2.60 & 2.30 & 2.54 & 1.60 & $1 / 5$ \\
Shortening & 2.00 & 2.00 & $<1$ & $<1$ & $<1$ & ND \\
\hline
\end{tabular}

${ }^{*}: \log \mathrm{cfu} / \mathrm{g}$

${ }^{* *}$ No. of positive samples/No. of tested samples

ND: not detected

$<1$ : viable colony was not detected at detection limit $<10^{1} \mathrm{cfu} / \mathrm{g}$

samples with percentage of $20 \%$. Salmonella sp. could be used as food safety criterion as reported by Virginia et al (2015). In the same time, according to ICMSF, (2011), Salmonella sp. should be not detected in milk powder.

Many microbiological control measures have multiple functions. Some microbiostatic control measures also have microbiocidal effects, the degree often depending upon the intensity at which they are applied (e.g. pH reduction, refrigeration, freezing, preservatives and indigenous antimicrobial systems), (CAC, 2013). In this study the investigated control measures applied for improving safety of the prepared filling cream are, thermal processing (pasteurization), addition of natural preservative (lemongrass oil and herbs of cinnamon, clove and anise) as well as reduction of $\mathrm{pH}$ (using fruit pulps).

The effect of pasteurization on the microbiological characteristics of prepared filling cream was shown in Table (6), It could be noticed the positive effect of pasteurized treatment in the reduction of different microbiological criteria of treated filling cream. Values of total bacterial count, spore forming bacteria, yeast \& mold counts, E. coli. and $S$. aureus. counts were 2.90, 2.78, 2.70, 2.60 and $2.00 \mathrm{log} \mathrm{cfu} / \mathrm{g}$ of untreated filling cream, respectively, furthermore Salmonella sp. was detected in 3 of 5 replicates of tested sample with percentage of $60 \%$. On the other hand, the aforementioned microbiological criteria of pasteurized filling cream were not detected at detection limit $<10^{1} \mathrm{cfu} / \mathrm{g}$, except spore forming bacteria which was decreased to $2.18 \log \mathrm{cfu} / \mathrm{g}$, in the same time, Salmonella $s p$. was not detected in any 5 replicate of tested samples. Many researches explained the effect of pasteurization on microorganisms as re- ported by Seema, (2015), therefore, pasteurization could be used as control measure for controlling pathogens in filling cream.

Results of microbiological analysis of prepared filling cream contained different concentrations of lemongrass oil are given in Table (7). Control filling cream (without any treatment) contained total bacterial count, spore forming bacteria, yeast \& mold counts, E. coli. and S. aureus. counts of 3.36, 2.93, $2.70,2.78$ and $2.81 \mathrm{log} \mathrm{cfu} / \mathrm{g}$, respectively, furthermore Salmonella $s p$. was detected in 3 samples of 5 replicates of tested samples with percentage of $60 \%$. From the same table it could be noticed that, as concentration of lemongrass oil increased the counts of aforementioned microbiological criteria were reduced in prepared filling cream, for example total bacterial count were reduced from $3.36 \mathrm{log} \mathrm{cfu} / \mathrm{g}$ of control filling cream to $2.60,2.17$ and $2.30 \mathrm{log} \mathrm{cfu} / \mathrm{g}$ of prepared filling cream contained 1,2 and $3 \mu \mathrm{l} / \mathrm{g}$ of lemongrass oil, respectively. Furthermore, detection percentage of Salmonella sp. for prepared filling cream contained the aforementioned concentrations of lemongrass was decreased to $20 \%$ as 1 of tested samples were positive per 5 replicate of tested samples when use a level $1 \mu \mathrm{l} / \mathrm{g}$, while not detected when using levels 2 and $3 \mu \mathrm{l} / \mathrm{g}$ of lemongrass oil. Lemongrass essential oil has antimicrobial activity against a diverse range of microorganisms including moulds, yeasts and gram positive and gram negative bacteria as reported by Nima et al (2014) and Asgar et al (2015). In general it could be noticed the antimicrobial effect of lemongrass oil but this effect was more little in comparison to pasteurization effect as mentioned earlier in Table (6). 
Table 6. Microbiological analysis of pasteurized filling cream

\begin{tabular}{|lcccccc|}
\hline $\begin{array}{c}\text { Prepared filling } \\
\text { cream }\end{array}$ & $\begin{array}{c}\text { Total } \\
\text { bacterial } \\
\text { count }^{*}\end{array}$ & $\begin{array}{c}\text { Spore forming } \\
\text { bacterial } \\
\text { count }^{*}\end{array}$ & $\begin{array}{c}\text { Yeast and } \\
\text { mold } \\
\text { count }^{\star}\end{array}$ & $\begin{array}{c}\text { E. } \\
\text { coli }^{\star} .\end{array}$ & S. aureus. ${ }^{*}$ & $\begin{array}{c}\text { Salmonella }^{* *} \\
\text { sp. }\end{array}$ \\
\hline Without treatment & 2.90 & 2.78 & 2.70 & 2.60 & 2.00 & $3 / 5^{\star *}$ \\
Pasteurization & $<1$ & 2.18 & $<1$ & $<1$ & $<1$ & $\mathrm{ND}$ \\
\hline
\end{tabular}

*: $\log \mathrm{cfu} / \mathrm{g}$

**No. of positive samples/No. tested samples

ND: not detected

$<1$ : viable colony was not detected at detection limit $<10^{1} \mathrm{cfu} / \mathrm{g}$

Table 7. Microbiological analysis of prepared filling cream contained different concentrations of lemongrass oil

\begin{tabular}{|c|c|c|c|c|c|c|}
\hline $\begin{array}{l}\text { Prepared filling } \\
\text { cream }\end{array}$ & $\begin{array}{l}\text { Total bacterial } \\
\text { count }^{\star}\end{array}$ & $\begin{array}{c}\text { Spore } \\
\text { forming } \\
\text { bacterial } \\
\text { count }^{\star}\end{array}$ & $\begin{array}{c}\text { Yeast and } \\
\text { mold } \\
\text { count }^{\star}\end{array}$ & E. coli*. & S. aureus.* & $\begin{array}{c}\text { Salmonella** } \\
\text { sp. }\end{array}$ \\
\hline Without treatment & 3.36 & 2.93 & 2.70 & 2.78 & 2.81 & $3 / 5^{* *}$ \\
\hline \multicolumn{7}{|c|}{ Concentration of lemongrass oil } \\
\hline $1 \mu \mathrm{l} / \mathrm{g}$ & 2.60 & 2.30 & 2.00 & 1.70 & 2.50 & $1 / 5^{\star *}$ \\
\hline $2 \mu \mathrm{l} / \mathrm{g}$ & 2.17 & 2.30 & $<1$ & $<1$ & $<1$ & ND \\
\hline $3 \mu \mathrm{l} / \mathrm{g}$ & 2.30 & 1.70 & $<1$ & $<1$ & $<1$ & ND \\
\hline \multicolumn{7}{|c|}{${ }^{*}: \log \mathrm{cfu} / \mathrm{g}$} \\
\hline \multicolumn{7}{|c|}{${ }^{\star \star}$ No. of positive samples/No. of tested samples } \\
\hline \multicolumn{7}{|c|}{ ND: not detected } \\
\hline
\end{tabular}

The best levels of strawberry, apricots and apple pulps achieved good sensory attributes with amounts of 20,18 and $20 \%$ were utilized for controlling $\mathrm{pH}$ of prepared filling cream (being 4.53, 4.68, and 4.57 for the aforementioned fruit pulps), and the microbiological results are shown in Table (8). Control filling cream prepared without any investigated fruit pulps contained total bacteria count, spore forming bacterial, yeast \& mold counts, E. coli. and S. aureus. counts of $2.85,2.60$, $2.60,2.30$ and $2.30 \mathrm{log} \mathrm{cfu} / \mathrm{g}$, respectively, furthermore Salmonella sp. was detected in 1 sample of 5 tested samples with percentage of $20 \%$. On the other hand, addition of different fruit pulps improved the safety of different prepared filling cream samples where different investigated microbiological criteria were reduced in comparison to control filling cream especially pathogenic criteria as $E$. coli. and $S$. aureus which were not detected at detection limit $<10^{1} \mathrm{cfu} / \mathrm{g}$. Furthermore, Salmonel- la sp. was not detected in any 5 tested samples. These results could be related to the reduction of $\mathrm{pH}$ of prepared filling cream and the antimicrobial effect of investigated fruit pulps. Fruits were investigated as sources of antimicrobial and antioxidants as presented naturally phenolic compounds, (Burt, 2004, Negi, 2012 and Silva et al 2014).

Microbiological analysis results of different prepared filling cream samples contained cinnamon, clove and anise with amounts of 3.0, 2.5 and 3.0\%, respectively (the best levels achieved good sensory attributes) were presented in Table (9). According to the tabulated results it could be noticed that, addition of different herbs improved the safety of filling cream. The microbiological criteria were reduced in comparison to control filling cream especially pathogenic criteria as E. coli. and $S$. aureus. and were not detected at detection limit $<10^{1}$ $\mathrm{cfu} / \mathrm{g}$. Furthermore, Salmonella sp. was not detected in any 5 tested samples. Antimicrobial of 
Table 8. Microbiological analysis of prepared filling cream contained different concentrations of natural fruit pulps

\begin{tabular}{|c|c|c|c|c|c|c|}
\hline $\begin{array}{l}\text { Prepared filling } \\
\text { cream }\end{array}$ & $\begin{array}{c}\text { Total bacterial } \\
\text { count }^{\star}\end{array}$ & $\begin{array}{c}\text { Spore forming } \\
\text { bacterial } \\
\text { count }^{\star}\end{array}$ & $\begin{array}{c}\text { Yeast and } \\
\text { mold } \\
\text { count }^{\star}\end{array}$ & E. coli* & S. aureus.* & $\begin{array}{c}\text { Salmonella** } \\
\text { sp. }\end{array}$ \\
\hline Without treatment & 2.85 & 2.60 & 2.60 & 2.30 & 2.30 & $1 / 5^{\star *}$ \\
\hline \multicolumn{7}{|c|}{ Natural fruit pulp concentration (\%) } \\
\hline Strawberry (20) & 2.00 & 2.00 & $<1$ & $<1$ & $<1$ & ND \\
\hline Apricots (18) & 2.30 & 2.00 & 2.00 & $<1$ & $<1$ & ND \\
\hline Apple (20) & 2.30 & 2.30 & 2.00 & $<1$ & $<1$ & ND \\
\hline
\end{tabular}

*: $\log \mathrm{cfu} / \mathrm{g}$

ND: not detected

**:No. of positive samples/No. tested samples

$<1$ : viable colony was not detected at detection limit $<10^{1} \mathrm{cfu} / \mathrm{g}$

Table 9. Microbiological analysis of prepared filling cream contained different concentrations of herbs

\begin{tabular}{|c|c|c|c|c|c|c|}
\hline $\begin{array}{l}\text { Prepared filling } \\
\text { cream }\end{array}$ & $\begin{array}{l}\text { Total bacterial } \\
\text { count }^{\star}\end{array}$ & $\begin{array}{l}\text { Spore forming } \\
\text { bacterial } \\
\text { count }^{\star}\end{array}$ & $\begin{array}{c}\text { Yeast } \\
\text { and mold } \\
\text { count }^{\star}\end{array}$ & $\begin{array}{c}E . \\
\text { coli*. }\end{array}$ & S. aureus.* & $\begin{array}{c}\text { Salmonella**} \\
\text { sp. }\end{array}$ \\
\hline Without treatment & 2.85 & 2.60 & 2.60 & 2.30 & 2.30 & $1 / 5^{\star *}$ \\
\hline \multicolumn{7}{|c|}{ Concentration of different herbs (\%) } \\
\hline Cinnamon (3.0) & 2.60 & 2.00 & $<1$ & $<1$ & $<1$ & ND \\
\hline Clove (2.5) & 2.70 & $<1$ & $<1$ & $<1$ & $<1$ & ND \\
\hline Anise (3.0) & 2.70 & 2.30 & 2.30 & $<1$ & 2.00 & ND \\
\hline
\end{tabular}

cinnamon was investigated and reported by Wang et al 2005, in the same time, anise oil was reported to be highly inhibitory to molds and fungi in food applications (Elgayyar et al 2001; Soliman and Badeaa, 2002).

According to the Fig. (1) of the flow diagram preparing steps of filling cream and using decision tree, (codex, 2003), critical control points (CCPs) of prepared filling cream were identified and the results are shown in Table (10). Receiving raw materials and whipping step were identified as CCPs for chemical and microbiological (pathogenic bacteria) hazards.

HACCP plan for filling cream preparation was presented in Table (11), as it could be shown the different principles of HACCP system critical control points, significant hazards, critical limits, monitoring procedures, corrective actions, verification procedures and records.
Table 10. Critical Control Points during preparation steps of filling cream

\begin{tabular}{|l|c|c|c|c|c|c|}
\hline $\begin{array}{c}\text { Preparing } \\
\text { step }\end{array}$ & Q 1 & Q 2 & Q 3 & Q 4 & CCP & Hazard \\
\hline $\begin{array}{l}\text { Receiving } \\
\text { raw materials } \\
\text { Whipping }\end{array}$ & Yes & Yes & No & No & Yes & No \\
Yes & No & Yes & microbiological \\
\hline
\end{tabular}

Codex, (2003).

Q1: Do control measures exist for the identified?

Q2: Does this step eliminates or reduces the likely occurrence of a hazard to an acceptable level?

Q3: Could contamination with identified hazard occur in excess of acceptable level or could it increase to unacceptable levels?

Q4: Will a subsequent step eliminate identified hazards or reduce the likely occurrence to an acceptable level? 


\section{CONCLUSION}

Microbiological hazards as pathogenic bacteria e.g. S. aureus, Salmonella sp. and E. coli in preparing filling cream are mainly attributable to the use of milk powder and inappropriate preparing conditions of whipping step. The obtained results of this study illustrated the positive effects of applicable a HACCP system during preparing steps of filling cream on the microbiological quality and the total safety of the final product. The application of the HACCP system provides bakeries and confectioneries manufacturers with effective control measures to guarantee the safety of prepared filling cream and also could be improved other products containing filling cream especially bakery products. This study introduced a simple HACCP system applicable and could be used as a guide for other related food products.

\section{REFERENCES}

APHA 2001. Compendium Method for the Microbiological Examination of Foods. $4^{\text {th }}$ Ed., American Public Health Association, Washington D.C, USA, pp. 223-226.

Asgar A., Mohd Noh. N and Maysoun A. Mustafa, 2015. Antimicrobial activity of chitosan enriched with lemongrass oil against anthracnose of bell pepper, Food Packaging and Shelflife, 3, 56-61.

Birkett, J. 2009. Fat-based centrs and fillings, Science and technology of enrobed and filled chocolate, confectionery and bakery products, Ed. Talbot G., WP \& CRC Press, Cambridge, UK. pp, 101-122.

Brack, G. 1996. HACCP and water activity. Brot. Backwaren, pp, 34- 44.

Burt, S. 2004. Essential oils: Their antibacterial properties and potential applications in food: A review. International Journal of Food Microbiology, 94, 223-253.

CAC (Codex Alimentarius Commission) 2003. Hazard analysis and critical control point (HACCP) system and guidelines for its application. Food hygiene basic text. Rome: FAO/WHO. Available at: http://www.codexalimentarius.org/standards/list -of-standards/.

CAC (Codex Alimentarius Commission) (2013). Principles and guidelines for the establishment and application of microbiological criteria related to foods (CAC/GL 21- 1997). Available at: http://www.codexalimentarius.org/standards/list -of-standards/.

Corlett, D.A. 1998. HACCP user's manual. Aspen Publishers, Inc. Maryland.

Elgayyar, M., Draughon, F.A., Golden, D.A. and Mount, J.R. 2001. Antimicrobial activity of essential oils from plants against selected pathogenic and saprophytic microorganisms. Journal of Food Protection, 64, 1019-1024.

Erol, S., Siriken, S., Siraii, UT., Kisa, O., Albay, A., Gun, H. and Haymez, S. 1996. Determination of microbial quality of cream pastries. Veteriner- Fakultesi- Dergisi- AnkaraUniversitesi, 43, p. 413.

FSSAI, Food Safety and Standard Authority of India, 2015. F. No., 1-110(2)/SP.

Gandhi, A.P. 2008. Development of HACCP Procedure for the Production of Full Fat Soy Flour. International Food Research Journal, 15(2), 141-154.

ICMSF (International Commission on Microbiological Specifications for Foods), 2005. Microorganisms in foods. Microbial Ecology of Food Commodities, 2 ${ }^{\text {ed }}$, Klnwer Academic/Plenum Publishers, New York. USA, pp. 643-716.

ICMSF (International Commission on Microbiological Specifications for Foods), 2011. Microorganisms in Foods 8: Use of Data for Assessing Process Control and Product Acceptance. Chapter 23. Milk and dairy products. Springer. pp. 305-327. New York. USA.

ICMSF (International Commission on Microbiological Specifications for Foods), 1980. Microbial Ecology of Foods. Factors affecting life and death of microorganisms. New York. USA: academic press, pp. 1-37.

ISO 6579 (International Standards Organization), 2002. Microbiology. General guidance on methods for the detection of salmonella. International Standards Organization, Geneva, Switzerland.

ISO 4833 (International Standards Organization), 2003. Horizontal method for the enumeration of microorganisms colony-count technique at $30^{\circ} \mathrm{C}$. International Standards Organization, Geneva, Switzerland.

ISO 6888-1 (International Standards Organization), 2003. Horizontal method for the enumeration of Coagulase positive staphylococci. International Standards Organization, Geneva, Switzerland. 
ISO 4832 (International Standards Organization), 2006. Microbiology of food and animal flour feeding stuffs - Horizontal method for the enumeration of coliforms - Colony-count technique. International Standards Organization, Geneva, Switzerland

ISO 21527-1 and 2 (International Standards Organization), 2008. Microbiology of food and animal feeding stuffs-Horizontal method for the enumeration of yeasts and moulds. International Standards Organization, Geneva, Switzerland.

Ledenbach, L.H. and Marshall, R.T. 2009. Compendium of the Microbiological Spoilage of Foods and Beverages, Food Microbiology and Food Safety, Springer Science+Business Media, LLC.

Leitenberger, E. and Röcken, W. 1998. HACCP in small bakeries, Food Control, 9, 151-155.

Manley D.J.R. 2001. Recipes for secondary processes, Biscuit, Cracker and Cookie Recipes for the Food Industry, Woodhead Publishing Ltd., Cambridge, UK, p. 135-154.

NACMCF (National Advisory Committee on Microbiological Criteria for Foods), 1992. Hazard analysis critical control point System. J. Food Microbial; 16, 1-23.

NACMCF (National Advisory Committee on Microbiological Criteria for Foods), 1998. Hazard analysis critical control point principles and application guidelines. Journal of Food Protection; 61, 1246-1259.

Negi, P.S. 2012. Plant extracts for the control of bacterial growth: Efficacy, stability and safety issues for food application. International Journal of Food Microbiology, 156, 7-17.

Nicoletta A.M., Di Monaco, R., Masia, P. and Cavellaa, S. 2015. Reduced-calorie filling cream: formula optimization and mechanical characterization, Chemical Engineering Transactions, 43, 1-6.

Nima A., Osman, A., Hasanah M. Ghazali, Chin Ping Tan and Noranizan M. Adzahan, 2014.
Lemongrass essential oil incorporated into alginate-based edible coating for shelf-life extension and quality retention of fresh-cut pineapple, Postharvest Biology and Technology, 88, 1-7.

Seema, R. 2015. Food Spoilage: Microorganisms and their prevention, Asian Journal of Plant Science and Research, 5, 47-56.

Silva, L.M.R., Figueiredo, E.A.T., Ricardo, N.M. P.S., Vieira, I.G.P., Figueiredo, R.W. and Brasil, I.M. 2014. Quantification of bioactive compounds in pulps and by-products of tropical fruits from Brazil. Food Chemistry, 143, 398404.

Sivasankar, B. 2002. Food Quality, In Food Processing and Preservation, Ed in 2002 by prentice-hall of India private limited, New Delhi. India, 345 p.

Soliman, K.M. and Badeaa, R.I. 2002. Effect of oil extracted from some medicinal plants on different mycotoxigenic fungi. Food and Chemical Toxicology, 40, 1669-1675.

Todd, E.C. 1978. Food borne disease in Canada1975 annual summary. Journal of Food Protection; 41(11), 910-918.

United Nations Codex Alimentarius Commission's Hazard analysis and critical control point (HACCP) and guidelines for its application. Annex to CAC/RCP 1-1969 (Rev. 4-2003). Available at: http://www.mhlw.go.jp/english/topics/

Virginia N. Scott, M. Powell, J. Cabrera, Maria E. Carullo, Inés Martinez and Lohachoompol, V. 2015. Development of microbiological criteria to assess the acceptability of a food lot - An example for milk powder, Food Control, 58, 12-16.

Wang, S.Y., Chen, P.F. and Chang, S.T. 2005. Antifungal activities of essential oils and their constituents from indigenous cinnamon (Cinnamomum osmophloeum) leaves against wood decay fungi. Bioresource Technology, 96, 813-818. 